\title{
Differentiated instruction, project-based learning, constructivist pedagogy principles
}

\author{
Saidova M.R. ${ }^{1}$, Ergasheva D.K. ${ }^{2}$ \\ ${ }^{1,2}$ Bukhara State University, Uzbekistan \\ Email: saidova_m@umail.uz
}

\begin{abstract}
The article deals the different type of project-based learning and its pedagogical principles. The importance of project-based learning method and its effectiveness was written here.
\end{abstract}

Keywords: teaching, method, skill, project-based learning, learning technologies.

\section{INTRODUCTION}

Times have changed, teachers have involved, and we now have a new breed of learning technologists. The first changes began in the classroom itself - new technologies such as overhead projectors, interactive whiteboards, laptop computers and wireless internet have opened up the classroom to the outside world. Now teachers adept at using PowerPoint to present grammar, playing podcasts to practice listening skills, pulling texts off the world wide web to introduce reading skills and perhaps most ground-breaking of all - empowering students by giving them access to a wide range of web-based tools that allow them to publish work and engage with live audiences in real contexts.

As the number of Russian learners is increasing different teaching methods have been implemented to test the effectiveness of the teaching process. It is true that these technologies have proved successful in replacing the traditional teaching. And below different methods are discussed that can effectively integrate technology in Russian language teaching.

The use of differentiated instruction in the classroom has proven to be the most effective way of assuring that every student's needs are being met. Every teacher has a different teaching style just as every student has different ways of learning in all content areas. By using differentiation, teachers recognize each student's needs. Thus, teachers can use a variety of engaging strategies that give students opportunities to use their strengths to develop their weaknesses. To assure that each student is provided with the opportunity to demonstrate what he/she has learned, teachers must promote student choice. As a result, instruction becomes student-focused rather than content-focused. Allowing students to choose the way in which they learn will motivate them to take ownership of their learning. With adequate preparation and support, differentiation can be successful in every classroom regardless of grade or ability. Although differentiated instruction is not relatively new, the extent to make it effective is still being learned as more teachers attempt to implement it within their own classrooms.

According to Tomlinson, differentiated instruction is a flexible approach to teaching in which the teacher plans and carries out varied approaches to the content, the process, or the product in anticipation of and in response to student differences in readiness, interests, and learning need.

Teachers direct their attention on methods and developments that guarantee successful learning for diverse students. Tomlinson also mentions that "Differentiated instruction properly implies the development of classrooms in which students sometimes exercise varied learning options, work at different paces, and are assessed with a variety of indicators appropriate to their interests and needs. It involves the enhancements of content, teaching, and evaluation to meet the needs of distinctive learners." One more successful approach of Russian language teaching that can incorporate with technology is Project Based Learning. Project Based Learning is a teaching methods in which students gain knowledge and skills by working for an extended period of time to investigate and respond to a complex question, problem, or challenge. There are several essential elements of PBL.

- Significant Content that focus of the project on teaching students important knowledge and skills, derived from standards and key concepts at the heart of academic subjects. 
- Students build competencies valuable for today's world, such as problem solving, critical thinking, problem solving, collaboration, communication, and creativity, innovation, which are clearly taught and assessed.

- In-Depth Inquiry - Students are engaged in an extended, rigorous process of asking questions, using resources, and developing answers.

- Project work is focused by an undefined question that students understand and find interesting, which captures their task or frames their exploration.

- Students see the need to gain knowledge, understand concepts, and apply skills in order to answer the driving question and create project products, beginning with an entry event that generates interest and curiosity.

- Students are allowed to make some choices about the products to be created, how they work, and how they use their time, guided by the teacher and depending on age level and PBL experience.

- The project includes processes for students to give and receive feedback on the quality of their work, leading them to make revisions or conduct further inquiry. Students present their work to other people, beyond their classmates and teacher.

The experience of thousands of teachers across all grade levels and subject areas, confirms that PBL is an effective and enjoyable way to learn. Today's students, more than ever, often find learning to be boring and meaningless. In PBL, students are active, not passive; a project engages their hearts and minds, and provides real-world relevance for learning. ${ }^{1}$

After completing a project, students remember what they learn and retain it longer than is often the case with traditional instruction. Because of this, students who gain content knowledge with PBL are better able to apply what they know and can do to new situations.

In the 21st century workplace, success requires more than basic knowledge and skills. In PBL, students not only understand content more deeply but also learn how to take responsibility and build confidence, solve problems, work collaboratively, communicate ideas, and be creative innovators.

The Common Core and other present-day standards emphasize real-world application of knowledge and skills, and the development of the 21 st century competencies such as critical thinking, communication in a variety of media, and collaboration. PBL provides an effective way to address such standards.

Modern technology - which students use so much in their lives - is a perfect fit with PBL. With technology, teachers and students can connect with experts, partners, and audiences around the world, and use technical tools to find resources and information, create products, and collaborate more effectively. ${ }^{2}$ PBL allows teachers to work more closely with active, engaged students doing high-quality, meaningful work, and in many cases to rediscover the joy of learning alongside their students. Current models of PBL are not like some past examples of "doing projects" in which student learning outcomes were not clear.

Project based learning with technology

Although it is not unusual for courses to have one or more projects as a part of them, in projectbased learning the project is at the center of the course, and learning builds on the basis of accumulating the skills and knowledge necessary to accomplish the project goals. Debski provides an example of this along with a well articulated rationale for what he calls "project-oriented" learning. In Debski's course, students worked collaboratively to build a website to support the Cultural Programs at the University of Melbourne. In addition to the website itself, students collectively produced a detailed project specification document, wrote essays on issues related to the project, and wrote an individual reflection paper describing their contributions to the project and what they had learned. Another example of project-based learning can be found, though in this case the projects are individual rather than collaborative. She describes the development of her CALL course over 2 years. In the first year, designing a Web Quest was the graduate project, but students in that course felt that it should have been started earlier. The following year the course was more clearly project based; as explains, "Following the teachers' suggestion, work on

${ }^{1}$ Palled M.\& Hill J. Practical Techniques. For Language Teaching. - London: Language Teaching Publications, 1995, 75p.

${ }^{2}$ Brush, T., and Saye, J. Implementation and evaluation of a student-centered learning unit: A case study. Educational Technology Research and Development, 48(3), 2000, 4p. 
the Web Quest project for the 2004 group started from the second week. The reading discussion which was originally done before the project was also carried out side by side with the project". 3

Constructivist teaching is based on constructivist learning theory. This theoretical framework holds that learning always builds upon knowledge that a student already knows; this prior knowledge is called a schema. Because all learning is filtered through pre-existing schemata, constructivists suggest that learning is more effective when a student is actively engaged in the learning process rather than attempting to receive knowledge passively. A wide variety of methods claim to be based on constructivist learning theory. Most of these methods rely on some form of guided discovery where the teacher avoids most direct instruction and attempts to lead the student through questions and activities to discover, discuss, appreciate and verbalize the new knowledge. ${ }^{4}$

\section{Constructivist teaching strategies}

One of the primary goals of using constructivist teaching is that students learn how to learn by giving them the training to take initiative for their own learning experiences.

According to Audrey Gray, the characteristics of a constructivist classroom are as follows:

* the learners are actively involved

* the environment is democratic

* the activities are interactive and student-centered

* the teacher facilitates a process of learning in which students are encouraged to be responsible and autonomous 5

\section{Examples of constructivist activities}

Furthermore, in the constructivist classroom, students work primarily in groups and learning and knowledge are interactive and dynamic. There is a great focus and emphasis on social and communication skills, as well as collaboration and exchange of ideas. This is contrary to the traditional classroom in which students work primarily alone, learning is achieved through repetition, and the subjects are strictly adhered to and are guided by a textbook. Some activities encouraged in constructivist classrooms are:

* Experimentation: students individually perform an experiment and then come together as a class to discuss the results.

\# Research projects: students research a topic and can present their findings to the class.

\# Field trips. This allows students to put the concepts and ideas discussed in class in a real-world context. Field trips would often be followed by class discussions.

* Films. These provide visual context and thus bring another sense into the learning experience.

* Class discussions. This technique is used in all of the methods described above. It is one of the most important distinctions of constructivist teaching methods.

Constructivist approaches can also be used in online learning. For example, tools such as discussion forums, wikis and blogs can enable learners to actively construct knowledge. Because existing knowledge schemata are explicitly acknowledged as a starting point for new learning, constructivist approaches tend to validate individual and cultural differences and diversity.

\section{Constructivism and Technology}

Instruction today faces two challenges. One challenge comes from the changing perceptions of what learning is all about. The second challenge comes from the new learning opportunities that technology now affords. Constructivism has presented the first challenge of reconceptualizing learning as a constructive process whereby information is turned into knowledge by means of interpretation, by actively relating it to existing bodies of knowledge, by the generative creation of representations, and by processes of purposeful elaboration.

Presenting the second challenge is the computer. Because of its usefulness and accessibility, its use in education may help to shift the foci from knowledge-as-possession to knowledge-as-construction and from learning as outside-guided to learning as self-guided. It also carries with it a renewed conception of instruction that shifts attention from instruction as the imparting of knowledge to instruction as the guidance of socially-based exploration in intellectually rich settings. ${ }^{6}$

\footnotetext{
${ }^{3}$ Wilkinson N. Vocabulary in Language Teaching. Cambridge- Cambridge University Press, 2008, 60p.

${ }^{4}$ Larsen-Freeman, D., Techniques and principles in language teaching. Oxford: University Press, 2000, 86p.

${ }^{5}$ Thornbury S. How to Teach Vocabulary. - London: Pearson Education Limited, 2010, 153p.

${ }^{6}$ Thorndike, E. L., Memory for paired associates. Psychological Review, 15, 2000
} 
It is no coincidence that these shifts, implied by the computer, happen to be highly congruent with the constructivist principles of learning and teaching. Constructivism and computing technology, separately and often together, have remade substantially the conception of the challenges of learning, and brought about new learning possibilities for almost all teaching and learning situations, including traditional classroom teaching, distance learning and self-learning. ${ }^{7}$

Constructivism provides ideas and principles about learning that have important implications for the construction of technology-supported learning environments. One of these implications is the need to embed learning into authentic and meaningful contexts. Here, students are required to engage actively in authentic problem-tackling or decision-making cases. There are numerous kinds of case-based learning environments. Among the better known forms are cognitive flexibility, hypertexts and anchored instruction. The central tenet of these forms of learning is improvement of students' understanding and their transfer of information through exposure to the same material, at different times, in rearranged contexts for different purposes.

Some researchers reported that computers were effective in developing higher-order thinking skills, including defining problems, judging information, solving the problems, and drawing appropriate conclusions. The computer can serve in the process of information gathering, inquiry, and collaboration, not merely as a sign of direct instruction with its reliance on integrating technology in the existing curriculum. Technology tools that aid in case-based learning include various types of simulation and strategy software/CD-ROMs, video discs, multimedia/hypermedia, and telecommunications (e-mail and Internet).

These tools present benefits including the ability to obtain relevant information in the form of documents, photographs, transcripts, video and audio clips; the capability of providing virtual experiences that otherwise would not be possible; and the opportunities for students to examine a variety of viewpoints so they can construct their own knowledge of various concepts. ${ }^{8}$

\section{CONCLUSION}

It is important that computer-supported constructivist environments should not involve the knowledge and intelligence to guide and structure learning processes, but rather should create situations and offer tools that stimulate students to make maximum use of their own cognitive potential.

Another important implication of constructivism for the construction of technology-supported learning environment is that learning is a personal, as well as a social activity. The penetration of technology into the learning process can have profound consequences for how learning takes place socially. On one side, one can see even more individual learning in a student sitting in front of his or her computer. But on the other hand, the technology allows for much more diversified and socially rich learning contexts; peer tutoring via computer; computer networks, e-mail, telecommunications.

\section{REFERENCES}

1. Palled M.\& Hill J. Practical Techniques. For Language Teaching. - London: Language Teaching Publications, 1995, 75p.

2. Brush, T., and Saye, J. Implementation and evaluation of a student-centered learning unit: A case study. Educational Technology Research and Development, 48(3), 2000, 4p.

3. Wilkinson N. Vocabulary in Language Teaching. Cambridge- Cambridge University Press, 2008, 60p.

4. Larsen-Freeman, D., Techniques and principles in language teaching. Oxford: University Press, 2000, 86p

5. Thornbury S. How to Teach Vocabulary. - London: Pearson Education Limited, 2010, 153p

6. Thorndike, E. L., Memory for paired associates. Psychological Review, 15, 2000

7. Swaffar, P. M. \& Woodruff, N., How languages are learned. Oxford: University Press, 1998, 74p

\footnotetext{
${ }^{7}$ Swaffar, P. M. \& Woodruff, N., How languages are learned. Oxford: University Press, 1998, 74p.

${ }^{8}$ Richard, J.C. \& Rogers, T.S., Approaches and methods in language teaching. Cambridge University Press, 1999, 93p.
} 